\title{
EARLIER OR LATER: A GENERAL EQUILIBRIUM ANALYSIS OF BRINGING FORWARD AN ALREADY ANNOUNCED TAX REFORM
}

\author{
JOSEF HONERKAMP \\ STEFAN MOOG \\ BERND RAFFELHUESCHEN
}

CESIFO WORKING PAPER NO. 1307

CATEgory 1: Public FinANCE

OCTOBER 2004

\footnotetext{
An electronic version of the paper may be downloaded

- from the SSRN website: Www.SSRN.com

- from the CESifo website: www.CESifo.de
} 


\title{
EARLIER OR LATER: A GENERAL EQUILIBRIUM ANALYSIS OF BRINGING FORWARD AN ALREADY ANNOUNCED TAX REFORM
}

\begin{abstract}
The German Income Tax Reform 2000, which announced a reduction in income tax rates to be implemented in a series of three stages, was welcomed by the public as a step towards unleashing lurking growth potentials. Nonetheless, in the course of the year 2001 a dispute arose, centering around the question as to whether or not the later stages of the German Income Tax Reform should be brought forward. The present paper assesses the welfare and macroeconomic consequences of the German Income Tax Reform in the scope of a simplified DGE model of the Auerbach-Kotlikoff type and deals explicitly with the issue of bringing forward an already announced tax reform. As well as evaluating the considered fiscal policy options in terms of their (social) welfare implications we also touch on the political economy aspects of implementing a tax reform.
\end{abstract}

JEL Code: H24, H31.

Keywords: German Tax Reform, early tax reform, overlapping generations, DGE model.

Josef Honerkamp

Albert-Ludwigs-University Freiburg

Department of Physics

Hermann-Herder-Str. 3

79104 Freiburg

Germany

hon@physik.uni-freiburg.de
Stefan Moog

Albert-Ludwigs-University Freiburg

Department of Economics

Bertoldstr. 17

79098 Freiburg

Germany

stefan.moog@vwl.uni-freiburg.de

Bernd Raffelhueschen

Institut fuer Finanzwissenschaft I

Albert-Ludwigs-University Freiburg

Platz der Alten Synagoge 1

79085 Freiburg

Germany

bernd.raffelhueschen@vwl.uni-freiburg.de

We would like to thank the participants of the Doctoral Seminar in Public Finance at the University of Freiburg for helpful comments. In particular, we thank Stefan Fetzer and Christian Hagist for helpful corrections and Dirk Mevis for valuable research assistance. Last but not least we would like to thank Annette Eckes from the Federal Statistical Office for providing us with the data. Finally, note that the present paper is a substantially revised version of the paper "Earlier or Later in CGE-Models: The Case of a Tax Reform Proposal". 


\section{Introduction}

With the adoption of the Tax Reduction Act by the German Bundestag, on July 6, 2000 and its approval by the Bundesrat, which represents the German states (Bundesländer), the German Tax Reform was passed into law by January 2001. Among other, one central element of the German Tax Reform was the reduction of income tax rates to be implemented in a series of three stages. It is this element - henceforth called the German Income Tax Reform (GITR) - which is in the very focus of this paper.

While the German Tax Reform was welcomed by the public as a step towards unleashing lurking growth potentials, in the course of the year 2001 a dispute arose which centered around the question of whether or not the later stages of the GITR should be brought forward as a means of stimulating the stuttering engine of the German economy. However, because of the floodings of the Elbe river in East Germany during the summer 2002 such a proposal was rejected. Instead, the proposal was reversed as the German government decided in the aftermath to postpone the already announced second stage of the GITR to January 1, 2004 in order finance the compensation payments to affected individuals and firms for their losses incurred. Nonetheless, for the same reasons as in 2001 a proposal to bring forward the last stage of the GITR became again top of the political agenda during the course of the year $2003 .{ }^{1}$ As a consequence of the public pressure the political decision makers agreed on a compromise, according to which the last stage of the GITR is partly brought forward to January 1, 2004 and is thus put into place together with the postponed second stage of the GITR. The remainder of the third stage will then follow on January 1 , 2005.

The focus of the present paper is twofold. First, we try to assess the welfare and macroeconomic effects of the GITR in the scope of a dynamic general equilibrium model calibrated to the macroeconomic conditions found in Germany. As such, the present paper is related to two strands in the literature. On the one hand the paper fits into the strand of literature concerning the effects of the German Tax Reform in general. While the present paper deals only with GITR the literature so far concentrated mainly on the effects of the German Business Tax Reform (GBTR). ${ }^{2}$ Within this literature only Sørensen (2002) and Strulik (2003) present an analysis of the effects of the GBTR in a general equilibrium framework. Sørensen (2002)

\footnotetext{
${ }^{1}$ Interestingly, during the dispute in 2001 the conservative opposition advocated in favor of bringing the tax reform forward, whereas the German government - a coalition of the Social Democrats and the Greens - refused such a proposal. The government argued that the expansionary effect of an early tax reform is too small and thus will fizzle out, while on the other hand an early tax reform, implying ceteris paribus a higher budget deficit, would conflict with the government's mid-term goal of presenting a balanced budget in 2006. Thus, government's resistance to bring forward the tax reform in 2001/02 may be seen as a means to build up their reputation as a consolidator of the national budget. However, during the dispute in 2003 the opponents interchanged their views on the matter. Here it was the government which advocated in favor of bringing the tax reform forward as a means of stimulating the economy, whereas the conservative opposition opposed such a proposal on the grounds of the burdens already imposed on future generations by the high level of explicit and implicit government debt.

${ }^{2}$ A short description of the central elements of the GBTR can be found in Homburg (2000) and Strulik (2003).
} 
analyzes the effects of the GBTR in the so called OECDTAX model which is a detailed general equilibrium model of the OECD economy. More in line with the analysis of the present paper is the study by Strulik (2003) who adopts a neoclassical growth framework in analyzing the 'supply-side economics' of the GBTR, i.e. the effects on capital accumulation and welfare of a representative agent. ${ }^{3,4}$

On the other hand, the paper fits into the literature on issues of taxation in dynamic general equilibrium models initiated by Summers (1981). From the onset this literature followed the evolution of models in macroeconomic and growth theory. Thus, beginning in the 1980s the neoclassical growth model with an exogenously given long run growth rate constituted the macroeconomic workhorse model. Besides Summers (1981), contributions which fit into this framework include the work by Judd (1985), Chamley (1986) and Auerbach and Kotlikoff (1987) to mention only a few. Following the development of endogenous growth theory in the 1980 s the literature turned to analyzing the same questions in a macroeconomic environment characterized by an endogenously determined long run rate of growth. Thereby the literature addressed the question of whether taxation affects the long run growth rate of an economy. Concentrating on human capital as the source of endogenous growth contributions in this line of research include Lucas (1990), King and Rebelo (1990), Jones, Manuelli, and Rossi (1993), Stokey and Rebelo (1995) and Grüner and Heer (2000). ${ }^{5}$ Summarizing this literature, reducing the rate of income taxation boosts the accumulation of both human and physical capital considerably in the long run and is accompanied by substantial long run welfare gains, even if the welfare losses during transition are taken into account. ${ }^{6}$ Moreover, while the welfare effects of reducing income tax rates are substantially magnified in endogenous growth models, the question of whether income taxation affects the long run growth rate of an economy is still open. ${ }^{7}$

However, in the light of the mentioned disputes in Germany of whether or not to bring forward the GITR a second question arises: Does such a fiscal policy step make any difference with respect to the welfare and macroeconomic effects of the tax reform package? As to our best knowledge no one has ever addressed this issue in the literature. On the one hand, the neglect of this issue may simply be explained by the

\footnotetext{
${ }^{3}$ While Strulik (2003) also includes the cut in the personal income tax rate, his analysis concentrates on the effects of the German Tax Reform which are induced by changes in corporate taxation.

${ }^{4}$ Besides the mentioned general equilibrium studies the effects of the GBTR are also discussed in a less formal manner by Leibfritz and Steinherr (1999), Sinn and Scholten (1999), Boss (2000), Homburg (2000), Schreiber (2000) and Keen (2002).

${ }^{5}$ See Milesi-Ferretti and Roubini (1998) for a survey of the qualitative growth effects of different forms of taxation in endogenous growth models.

${ }^{6}$ While reviewing the literature we concentrated on representative agent models with finite or infinite horizons. However, in the scope of a heterogenous agent model reducing the tax rate on capital income may be accompanied with a welfare loss as pointed out by Aiyagari (1995). He finds that the actual capital income tax rate in the US may indeed be optimal in a calibrated version of his model.

${ }^{7}$ Considering the empirical evidence for the US Stokey and Rebelo (1995) find that the dramatic rise in income tax revenue in the early 1940s had no statistically significant effect on the growth rate of the US economy. Nonetheless, even if the growth effects of tax reforms are small, the welfare effects may still be substantial as small changes in an economy's growth rate accumulate over time, thereby affecting the level of macroeconomic variables substantially in the long run.
} 
fact that such a fiscal policy step would result in only minor differences with respect to the long run impact of the conducted tax reform, while the short and medium run effects are merely brought forward? On the other hand, it is well known that in absence of bequests Ricardian Equivalence doesn't hold in life-cycle economies populated by finitely living representative agents. Hence, the long run impacts of any fiscal policy depend crucially on the intergenerational distribution of its benefits and costs over time. Therefore and second, we try to shed some light on this issue in the scope of an overlapping generations model encompassing 59 generations and an endogenous labor supply decision. Specifically, we confront the option of conducting the GITR as originally scheduled with the option of bringing it forward. Besides evaluating the different fiscal policy options in terms of their (social) welfare implications we also touch on the political economy aspects of implementing a tax reform by asking whether a policy option will receive the political support from a majority of the electorate.

The remainder of the paper is organized as follows: Section 2 specifies the model, while section 3 offers a description of the model's calibration. The details of the investigated GITR as well as our results are presented in Section 4. Finally, section 5 summarizes our findings and concludes the paper. An appendix comments on the methodology applied to solve the model numerically.

\section{The Model}

In order to simplify the analysis, we consider a highly stylized closed economy overlapping generations model in the spirit of Samuelson (1958), Diamond (1965) and Auerbach and Kotlikoff (1987). At every point in time the economy is populated by $I$ types of individuals (denoted by $i=1, \ldots, I$ ) which differ with respect to age. Specifically, at the beginning of each period $t$ there is a 'newly born' youngest generation $i=1$ just entering the labor force. At the end of each period the members of the oldest generation $i=I$ die with certainty, while the members of each younger generation $i(i=1, \ldots, I-1)$ grow one 'year' older and constitute the generation $i+1$ in the next period. Moreover, the population grows at a constant rate $\eta$. Let the mass of individuals entering the labor force in period $t=0$ be normalized to one. Then, if we denote the mass of individuals of generation $i$ at time $t$ by $L_{i}(t)$ the demographic process for the economy is summarized by

$$
L_{i}(t+1)=(1+\eta) L_{i}(t)
$$

and

$$
L_{i}(0)=(1+\eta)^{1-i}
$$

Thus the population of the economy is stable, implying that the relative sizes of the cohorts do not change over time. 


\subsection{Households}

In each period $t$ the representative household of generation $i$ chooses consumption of goods and leisure over its remaining life-time to maximize the time-separable utility function

$$
U_{i}(t)=\sum_{k=0}^{I-i} \beta^{k} u\left(c_{i+k}(t+k), l_{i+k}(t+k)\right),
$$

where $c_{i}(t)$ and $l_{i}(t)$ denote the consumption of goods and leisure of the representative household of generation $i$ in period $t$, while $\beta$ denotes the household's discount factor which reflects pure time preference. The period utility function $u(c, l)$ is assumed to be of the CRRA type and given by

$$
u(c, l)=\frac{\left(c^{\phi} l^{1-\phi}\right)^{1-\rho}}{1-\rho}
$$

where $1 / \rho$ represents the (constant) intertemporal elasticity of substitution between consumption in different periods of life and $\phi$ is a parameter determining the household's preference for leisure.

Normalizing an individual's time endowment to unity, the representative household of generation $i$ supplies $1-l_{i}(t)$ units of raw labor in period $t$. In order to generate a realistic life-cycle earnings profile we assume that the household effectively supplies $\epsilon_{i}$ efficiency units for each unit of raw labor supplied. Besides wage income an individual receives interest income on assets accumulated in the past. Thereby the asset holdings of the representative household of generation $i$ at the beginning of period $t$ are denoted by $a_{i}(t)$. Furthermore, households have to pay a personal income tax $\tau_{i}(t)$ on labor and capital income. We assume that the tax system is given or may be approximated by a flat-rate tax

$$
\tau_{i}(t)=\left(w(t) \epsilon_{i}\left(1-l_{i}(t)\right)+r(t) a_{i}(t)\right) \tau_{y}(t),
$$

where $\tau_{y}(t)$ denotes the income tax rate in period $t$. Next, while we do not explicitly introduce any transfer payments, e.g. pensions, into our model, the government levies a lump sum tax $-\operatorname{tr}(t)$, i.e. a negative transfer, on all individuals alive in period $t$ to ensure that its intertemporal budget constraint is balanced in the long run. ${ }^{8}$ Finally, net income can be saved to accumulate further assets $\left(a_{i+1}(t+1)\right)$ or spent on consumption goods $\left(c_{i}(t)\right)$, where consumption expenditures are subject to a sales tax $\tau_{c}$, which we assume constant over time.

Hence, denoting the gross wage rate for raw labor by $w(t)$ and the gross interest rate by $r(t)$, the period $t$ budget constraint of the representative household of generation $i$ reads

$$
\begin{aligned}
\left(1+\tau_{c}\right) c_{i}(t) & =(1+r(t)) a_{i}(t)+\epsilon_{i}\left(1-l_{i}(t)\right) w(t)+\operatorname{tr}(t)-\tau_{i}(t)-a_{i+1}(t+1) \\
& =(1+\tilde{r}(t)) a_{i}(t)+\epsilon_{i}\left(1-l_{i}(t)\right) \tilde{w}(t)+\operatorname{tr}(t)-a_{i+1}(t+1),
\end{aligned}
$$

\footnotetext{
${ }^{8}$ While the transfer is indeed a lump sum tax, we still denote the variable $\operatorname{tr}(t)$ as transfers and interpret it as the cut in transfer payments necessary to restore long run intertemporal budget balance. Thereby the change in utility following the tax reform scenarios considered in later sections also reflects the cost of these reforms.
} 
where $\tilde{r}(t)=\left(1-\tau_{y}(t)\right) r(t)$ and $\tilde{w}(t)=\left(1-\tau_{y}(t)\right) w(t)$. As we abstract from any bequest motives and since there is no uncertainty concerning the deterministic life-span, the oldest generation $I$ being in their last life-cycle phase in period $t$ consumes their entire wealth, while the asset level of the youngest generation $i=1$ is equal to zero, i.e.

$$
\begin{aligned}
a_{I+1}(t+1) & =0 \\
a_{1}(t) & =0
\end{aligned}
$$

Given the utility function in equation (3), the budget constraint in equation (5), and the terminal and initial conditions in equations (6) and (7) individuals choose consumption and leisure in each period such that utility over their remaining life-time will be maximized.

\subsection{Production Technology}

Competitive firms use labor and capital to produce output which can be used for both consumption and investment. Production is characterized by constant returns to scale which ensures that the present value of the firms' profits will vanish in a world of perfectly competitive good markets. Because firm size is indeterminate under constant returns to scale, we can think of production as being carried out by a single representative firm. For simplicity we assume that the production technology of this representative firm is given by a Cobb-Douglas production function

$$
Y(t)=F(K(t), X(t) N(t))=(K(t))^{\alpha}(X(t) N(t))^{1-\alpha}
$$

where $Y(t), K(t)$, and $N(t)$ are output, capital, and labor input at time $t . \alpha$ reflects the share of capital income and $1-\alpha$ the total labor income share on GDP, while $X(t)$ reflects labor augmenting technical progress at rate $\gamma \geq 0$, i.e. $X(t)$ follows the deterministic process

$$
X(t+1)=(1+\gamma) X(t)
$$

Moreover, without loss of generality we can normalize labor productivity in the initial period $t=0$ to one, implying that $X(t)=(1+\gamma)^{t}$. Assuming that the amount of labor and capital employed can be adjusted costlessly, perfect competition on capital and labor markets implies that factors of production are paid their marginal product, that is

$$
\begin{aligned}
w(t) & =F_{N}(K(t), X(t) N(t))=(1-\alpha) K(t)^{\alpha} X(t)^{1-\alpha} N(t)^{-\alpha} \\
r(t) & =F_{K}(K(t), X(t) N(t))-\delta=\alpha K(t)^{\alpha-1} X(t)^{1-\alpha} N(t)^{1-\alpha}-\delta .
\end{aligned}
$$


According to equation (9) labor should be employed up to the point where the marginal product of labor equals the wage rate $w(t)$, while equation (10) demands that the expected marginal product of capital should be equal to the user cost of capital $r(t)+\delta$.

Finally, aggregate factor inputs in period $t$ are given by

$$
\begin{aligned}
& N(t)=\sum_{i=1}^{I} \epsilon_{i}\left(1-l_{i}(t)\right) L_{i}(t) \\
& K(t)=\sum_{i=1}^{I} L_{i}(t) a_{i}(t)-B(t),
\end{aligned}
$$

where $B(t)$ denotes the level of government debt in period $t$.

\subsection{Public Sector}

The public sector acts according to the unified budget principle, that is combined tax revenues finance total expenditures. Tax revenues $T(t)$ consist of two components: 1) a comprehensive income tax on both labor and capital income, and 2) a consumption tax in line with the VAT. Thus the government's overall tax revenue in period $t$ is given by

$$
T(t)=\sum_{i=1}^{I} L_{i}(t)\left(\tau_{i}(t)+\tau_{c} c_{i}(t)\right) .
$$

The government expenditures in period $t$ are given by $G(t)$ which reflects the government's real purchase of goods and services. Throughout we assume that the government always consumes a constant fraction $g$ of GDP so that government expenditures are given by $G(t)=g Y(t)$. Moreover, to finance its expenditures the government collects not only taxes but also draws resources from the private sector by issuing bonds $B(t+1)$ which are annually repayed and served with the interest rate prevailing in the economy. Finally, as was noted above, in the periods following the implementation of a tax reform scenario the government levies a lump sum tax $-\operatorname{tr}(t)$ on all individuals alive in period $t$ to balance its intertemporal budget in the long run. Specifically, as of some period $0<\bar{t}<\infty$ the government chooses this lump sum tax such that the level of government debt (adjusted for population and productivity growth) remains constant until the economy reaches its new balanced growth path. Hence, the budget constraint of the public sector is given by

$$
B(t+1)-B(t)=r(t) B(t)+G(t)+T R(t)-T(t),
$$

where

$$
\begin{aligned}
T R(t) & =\left\{\begin{array}{cl}
0 & \text { for } t<\bar{t}, 0<\bar{t}<\infty \\
(\nu-r(t)) B(t)-G(t)+T(t) & \text { otherwise }
\end{array}\right. \\
\operatorname{tr}(t) & =\frac{T R(t)}{L(t)}
\end{aligned}
$$


and $\nu=(1+\gamma)(1+\eta)-1$ denotes the growth rate of GDP along a balanced growth path.

\subsection{Equilibrium}

For a feasible government policy a competitive equilibrium of the economy just described is comprised of (i) the solution to the household's utility maximization problem, (ii) the solution to the firm's profit maximization problem and (iii) market clearing on goods and factor markets.

However, while the definition of equilibrium just given corresponds to the standard notion of equilibrium familiar from the theory of general equilibrium, it is not well suited for computational purposes as noted by Ríos-Rull (1996). Especially, if one formulates the problem at hand using the theory of dynamic programming, the appropriate notion of equilibrium is recursive competitive equilibrium. ${ }^{9}$

Before defining a recursive competitive equilibrium for our case, we first have to deal with the issue of stationarity. More precisely, because of population and labor productivity growth the economy just described is not stationary. But in the case of the assumed CRRA utility function it is possible to transform the economy such that the transformed economy is stationary. ${ }^{10}$ Except for leisure individual variables will grow with the rate of labor productivity $(1+\gamma)$ along a balanced growth path, while aggregate variables grow at a rate $(1+\eta)(1+\gamma)$ with the exception of aggregate labor input which grows only at a rate $(1+\eta)$. Hence, stationarity can be achieved by simply dividing all individual variables as of period $t$ by $X(t)$, while aggregate variables have to be divided by $X(t) L(t)$. Thereby we eliminate the deterministic trend present in the original economy. Furthermore, we have to adjust the wage rate for labor productivity growth by dividing it by $X(t)$. To finish the transformation we also have to adjust the individual discount rate $\beta$. Given the assumed CRRA form of the utility function this adjusted discount rate in the transformed economy is given by $\beta^{*}=\beta(1+\gamma)^{\phi(1-\rho)}$. Applying the described transformations and ignoring for the moment the dependence on time we arrive at the following definitions of variables in the transformed, stationary economy:

$$
\begin{aligned}
& \hat{a_{i}}=a_{i} / X, \hat{c_{i}}=c_{i} / X, \hat{t r}=\operatorname{tr} / X, \hat{l_{i}}=l_{i} \\
& \hat{B}=B /(X L), \hat{T}=T /(X L), \hat{G}=G /(X L), \hat{T R}=T R /(X L) \\
& \hat{K}=K /(X L), \hat{N}=N / L, \hat{w}=w / X, \hat{r}=r
\end{aligned}
$$

Secondly, adopting a recursive formulation for describing the model's solution requires one to think about the relevant state variables. In our case the aggregate state of the economy at any point in time is fully

\footnotetext{
${ }^{9}$ The notion of recursive competitive equilibrium was introduced by Prescott and Mehra (1980). See also Ríos-Rull (1996) and Ljungqvist and Sargent (2000).

${ }^{10}$ See King, Plosser, and Rebelo (1988) and Ríos-Rull (1996).
} 
described by the economy-wide distribution of assets and the level of government debt, as these variables determine the economy's capital stock. Moreover, because of the considered tax reforms, the economic environment changes over time such that the aggregate state of the economy depends explicitly on time. From the perspective of the individual one has to add to these aggregate states the asset holdings of the individual as an additional state variable.

Now, we are prepared for defining a recursive competitive equilibrium for the transformed economy. Denoting the economy-wide distribution of assets in the transformed economy by $\hat{A}=\left(\hat{a}_{1}, \ldots, \hat{a}_{I}\right)$ let $\hat{Z}=$ $(\hat{A}, \hat{B})$. Moreover, let $\mu_{i}=L_{i}(0) / L(0)=L_{i}(t) / L(t)$ denote generation $i$ 's share on the total population. Then, denoting next period variables by a prime $\left({ }^{\prime}\right)$ we have:

Definition: For a given path of income tax rates $\left\{\tau_{y}(t)\right\}_{t=0}^{\infty}$, a recursive competitive equilibrium is comprised of a sequence of value functions $\left\{V_{i}(\hat{a}, \hat{Z}, t)\right\}_{i=1}^{I}$ with corresponding policy functions for next periods assets $\left\{\hat{a}_{i}^{\prime}(\hat{a}, \hat{Z}, t)\right\}_{i=1}^{I}$, consumption $\left\{\hat{c}_{i}(\hat{a}, \hat{Z}, t)\right\}_{i=1}^{I}$ and leisure $\left\{l_{i}(\hat{a}, \hat{Z}, t)\right\}_{i=1}^{I}$, functions determining aggregate factor inputs $\hat{K}(\hat{Z}, t)$ and $\hat{N}(\hat{Z}, t)$, functions determining factor prices $\hat{w}(\hat{Z}, t)$ and $\hat{r}(\hat{Z}, t)$ and laws of motion for the economy-wide asset distribution $\left\{\hat{H}_{i}(\hat{Z}, t)\right\}_{i=1}^{I}$ and government debt $\hat{J}(\hat{Z}, t)$ for all $t$, such that

(a) the resulting allocation is feasible, i.e.

$$
\begin{aligned}
& \sum_{i=1}^{I} \mu_{i}\left(\hat{c}_{i}\left(\hat{a}_{i}, \hat{Z}, t\right)+(1+\nu) \hat{a}_{i}^{\prime}\left(\hat{a}_{i}, \hat{Z}, t\right)\right)-(1+\nu) J(\hat{Z}, t)= \\
&(1-g) F(\hat{K}(\hat{Z}, t), \hat{N}(\hat{Z}, t))-(1-\delta)\left(\sum_{i=1}^{I} \mu_{i} \hat{a}_{i}-\hat{B}\right)
\end{aligned}
$$

(b) factor prices equal marginal productivities, i.e.

$$
\begin{aligned}
\hat{w}(\hat{Z}, t) & =F_{N}(\hat{K}(\hat{Z}, t), \hat{N}(\hat{Z}, t)) \\
\hat{r}(\hat{Z}, t) & =F_{K}(\hat{K}(\hat{Z}, t), \hat{N}(\hat{Z}, t))-\delta
\end{aligned}
$$

(c) aggregate factor inputs are given by

$$
\begin{aligned}
\hat{K}(\hat{Z}, t) & =\sum_{i=1}^{I} \mu_{i} \hat{a}_{i}-\hat{B} \\
\hat{N}(\hat{Z}, t) & =\sum_{i=1}^{I} \mu_{i} \epsilon_{i}\left(1-l_{i}\left(\hat{a}_{i}, \hat{Z}, t\right)\right)
\end{aligned}
$$


(d) taking the functions determining aggregate factor input and factor prices, as well as the laws of motion for the asset distribution and government debt as given, the value and policy functions solve the Bellman equation associated with the household's maximization problem

$$
\begin{aligned}
V_{i}(\hat{a}, \hat{Z}, t)=\max _{\hat{a}^{\prime}, \hat{c}, \hat{l}} \quad\left\{u(\hat{c}, \hat{l})+\beta^{*} V_{i+1}\left(\hat{a}^{\prime}, H(\hat{Z}, t), J(\hat{Z}, t), t+1\right)\right\} \\
\text { s.t. } \quad\left(1+\tau_{c}\right) \hat{c}+(1+\gamma) \hat{a}^{\prime}=(1+\hat{\tilde{r}}(\hat{Z}, t)) \hat{a}+\epsilon_{i}(1-\hat{l}) \hat{\tilde{w}}(\hat{Z}, t)+\hat{t r}(\hat{Z}, t) \\
\hat{a}^{\prime}=0, \text { if } i=I \\
\hat{a} \quad=0, \text { if } i=1 \\
\\
V_{I+1}\left(\hat{a}^{\prime}, H(\hat{Z}, t), J(\hat{Z}, t), t+1\right)=0,
\end{aligned}
$$

where $\hat{\tilde{w}}(\hat{Z}, t)=\left(1-\tau_{y}(t)\right) \hat{w}(\hat{Z}, t)$ and $\hat{\tilde{r}}(\hat{Z}, t)=\left(1-\tau_{y}(t)\right) \hat{r}(\hat{Z}, t)$.

(e) the law of motion for the economy-wide asset distribution satisfies

$$
\begin{aligned}
H_{i}(\hat{Z}, t) & =0, \text { if } i=1 \\
H_{i+1}(\hat{Z}, t) & =\hat{a}_{i}^{\prime}\left(\hat{a}_{i}, \hat{Z}, t\right), \text { for } i=1, \ldots, I-1
\end{aligned}
$$

(f) the law of motion for government debt obeys

$$
(1+\nu) J(\hat{Z}, t)=(1+\hat{r}(\hat{Z}, t)) \hat{B}+g F(\hat{K}(\hat{Z}, t), \hat{N}(\hat{Z}, t))+\hat{T R}(\hat{Z}, t)-\hat{T}(\hat{Z}, t)
$$

(g) tax revenue is given by

$$
\hat{T}(\hat{Z}, t)=\sum_{i=1}^{I} \mu_{i}\left[\tau_{y}(t)\left(\hat{r}(\hat{Z}, t) \hat{a}_{i}+\epsilon_{i}\left(1-\hat{l}_{i}\left(\hat{a}_{i}, \hat{Z}, t\right) \hat{w}(\hat{Z}, t)\right)\right)+\tau_{c} \hat{c}_{i}\left(\hat{a}_{i}, \hat{Z}, t\right)\right],
$$

(h) aggregate and individual transfers are given by

$$
\begin{aligned}
& \hat{T R}(\hat{Z}, t)=\left\{\begin{array}{cl}
0 & \text { for } t<\bar{t}, 0<\bar{t}<\infty \\
(\nu-\hat{r}(\hat{Z}, t)) \hat{B}-g F(\hat{K}(\hat{Z}, t), \hat{N}(\hat{Z}, t))+\hat{T}(\hat{Z}, t) & \text { otherwise }
\end{array}\right. \\
& \hat{\operatorname{tr}}(\hat{Z}, t)=\hat{T R}(\hat{Z}, t) .
\end{aligned}
$$

Before proceeding let us first comment on the equilibrium conditions. Condition (a) is merely the aggregate feasibility constraint according to which output equals the sum of consumption, investment and government expenditure, while condition (b) implies profit maximization on the part of the firms. Next, condition (c) implies market clearing on factor markets, while condition (d) implies utility maximization on the part of the households for given laws of motion for the aggregate states. According to condition (e) the law of motion for the economy-wide asset distribution coincides with the individual policy 
functions for next period's assets. Hence, as all agents are born with no assets the first equation merely states that the assets of next period's generation 1 are zero, while the assets of next period's generations $i+1, i=1, \ldots, I-1$ evolve according to this period's generation $i$ 's policy function for next period assets. Finally, condition (f) demands that the law of motion for government debt satisfies the government's per period budget constraint, while conditions (g) and (h) replicate equations (13) and (15) which specify the composition of aggregate tax revenue and our chosen rule for the path of lump sum taxes needed to restore intertemporal budget balance.

\section{Calibration}

To add realism to the numerical simulations, we employ empirically significant parameter estimates from the literature. Where these are not available, indirect methods and ad hoc assumptions have to be made. Although our simulation approach yields numerical insights into real world policy making, the illustrative character of the results should be borne in mind. The model's starting-point for the different tax reform proposals is calibrated to macroeconomic conditions, the legal system, and institutional settings presently found in Germany (See Table (1) for a summary of the parameter values in our benchmark calibration and Table (2) for a summary of the implied steady state values for major macroeconomic variables). ${ }^{11}$

Demographics As the expected lifetime of an representative individual at age 20 amounted to approximately 78 years in 1999, the span of the life-cycle of an individual at age 20 amounts to 59 years. ${ }^{12}$ Thus we set $I=59$ in our model economy which thereby constitutes 59 overlapping generations. Furthermore, in line with the demographics in Germany, we assume that the population grows with an annual rate of 0.25 percent per annum, which corresponds to the average over the period 1980-2000. Hence, the population growth rate $\eta$ is set to .0025 . Finally, given our calibration individuals stop working at the age of 59 (model period 40). While this figure is lower than the legal retirement age of 65 , it actually corresponds very well to the average retirement age which as a result of the possibilities and incentives for early retirement amounted to the age of 60 in 2000 (VDR (2002), p. 111). However, while the implementation of the tax reform may result in an earlier or later age of retirement, we impose the restriction that individuals stop working at the age of 59 in order to simplify the computation of the transition path to the final

\footnotetext{
${ }^{11}$ If not otherwise stated, the data is taken from the National Income and Product Accounts for Germany (Volkswirtschaftliche Gesamtrechnungen) and the Statistical Yearbook for the Federal Republic of Germany (Statistisches Jahrbuch für die Bundesrepublik Deutschland). Both data sources are published by the Federal Statistical Office (Statistisches Bundesamt).

${ }^{12}$ The expected lifetime of a male (female) individual at age 20 amounted to 75 (81) years in 1999. Taking into account the composition of the population, i.e. the share of male (female) individuals at age 20 or older but younger than 76 ( 82 ) in the population amounted to 48.2 (51.8) percent in 2000, we thus computed the expected lifetime of an average individual.
} 


\begin{tabular}{lc}
\hline \hline Parameter & Value \\
\hline \hline Life-Cycle $(I)$ & 59 \\
Population growth rate $(\eta)$ & .0025 \\
Rate of technical progress $(\gamma)$ & .0209 \\
Elasticity of substitution between consumption and leisure $(\phi)$ & .31 \\
Intertemporal elasticity of substitution $(1 / \rho)$ & .3 \\
Individual discount factor $(\beta)$ & 1.011 \\
Income tax rate $\left(\tau_{y}\right)$ & .177 \\
Consumption tax rate $\left(\tau_{c}\right)$ & .16 \\
Ratio of government expenditure to GDP $(g)$ & .19 \\
Production Elasticity of Capital $(\alpha)$ & .36 \\
Depreciation Rate of Capital $(\delta)$ & .051 \\
\hline \hline
\end{tabular}

Table 1: Benchmark calibration of the model parameters

\begin{tabular}{cccccccccc}
\hline \hline Macroeconomic variable & $K / Y$ & $I / K$ & $C / Y$ & $I / Y$ & $B / Y$ & $T_{Y} / Y$ & $T_{C} / Y$ & $T / Y$ & $r$ \\
Implied value & 3.022 & .0745 & .585 & .225 & 1.6348 & .1694 & .0936 & .263 & .0681 \\
\hline \hline
\end{tabular}

Table 2: Values of major macroeconomic variables along the initial balanced growth path implied by the benchmark calibration

steady state.

Households Following Hirte (2002) we set the intertemporal elasticity of substitution on a value of .3, which implies a value of approximately 3.33 for the risk aversion parameter $\rho$. As in Ríos-Rull (1996) the elasticity of substitution between consumption and leisure is chosen such that the average labor supply corresponds to one third of the overall time endowment in the initial steady state. This is accomplished by setting $\phi$ equal to .31. In accordance with Ríos-Rull (1996) we choose a value of 1.011 for the individual discount factor $\beta$. Finally, to generate a realistic life-cycle earnings profile we calibrate the $\epsilon(i)$ 's using data from the Socioeconomic Panel for Germany (SOEP). Specifically, using data on annual earnings and supply of labor hours we computed the implied supply of efficiency units over the life-cycle. After normalizing by the supplied efficiency units of a 20 year old individual the resulting supply of efficiency units over the life-cycle is depicted in Figure 1.

Government While in the case of infinite horizon representative agent models Lucas (1990) and Mendoza, Razin, and Tesar (1994) advocate for the use of average effective tax rates in calibrating income tax rates, such a clear cut strategy is not available in the case of overlapping generations models. Nonetheless we decided to follow this strategy in using the effective tax rate on personal income provided by Martinez- 


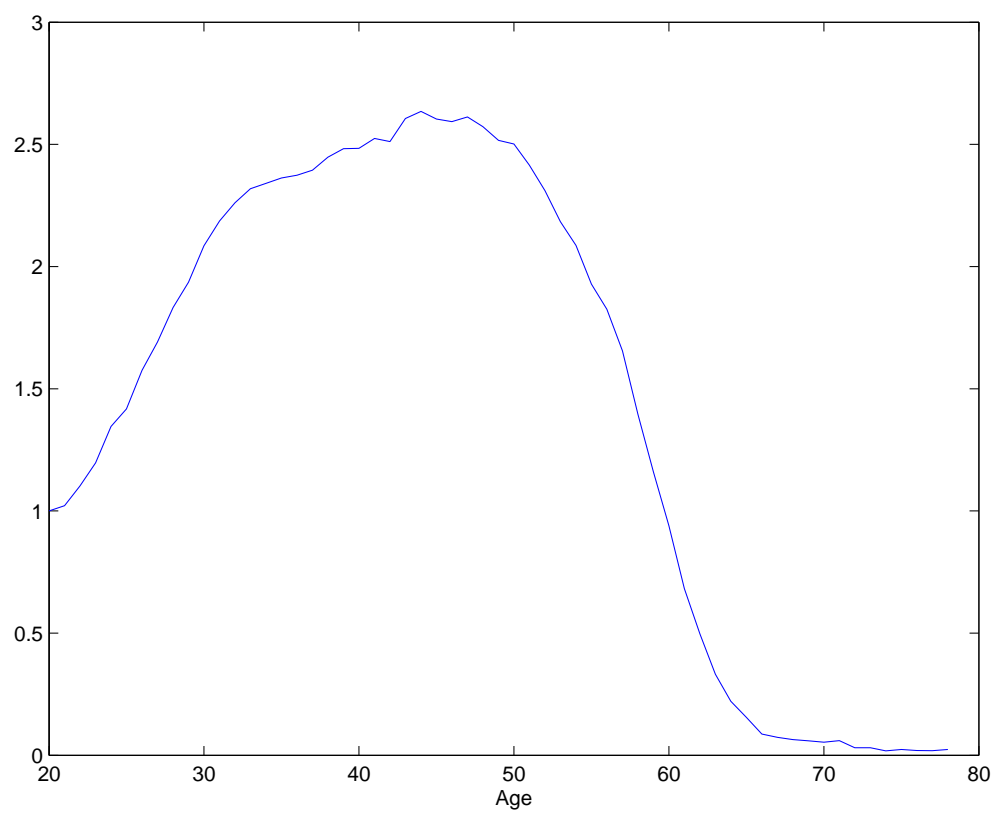

Figure 1: Supply of efficiency units over the life-cycle

Mongay (2000) as our measure of the income tax rate in the initial steady state. ${ }^{13}$ As a spin-off the use of this effective tax rate, which amounted to 17.7 percent in 2000, together with the calibration of the production technology's parameters described below generates ratios of investment to augmented GNP and capital to augmented GNP which correspond very well to the averages found in the data over the period 1980-2000. ${ }^{14}$ Hence, in our benchmark calibration we set the income tax rate $\tau_{y}$ equal to .177 . Next, as in the legal system of Germany we choose a value of 16 percent for the consumption tax rate. Hence, $\tau_{c}$ is set equal to .16. Finally, as the average ratio of government expenditure to GDP over the period 1980-2000 amounted to 19 percent we set the parameter $g$ on a value of .19. However, note that our calibration induces a ratio of government debt to GDP of 163 percent along the initial balanced growth path which is substantially higher than the value in 2000 which amounted to 59 percent. ${ }^{15}$

\footnotetext{
${ }^{13}$ Note that the procedure used by Martinez-Mongay (2000) in computing effective tax rates differs somewhat from the one adopted by Mendoza, Razin, and Tesar (1994) and Carey and Tchilinguirian (2000). However, compared to these other studies the effective tax rates provided by Martinez-Mongay (2000) range up to the year 2001. More importantly corresponding to the income tax rate in our model he provides a comprehensive measure of the income tax rate including both income from capital and labor.

${ }^{14}$ As described below our definition of the economy's capital stock includes the government's capital stock. Therefore, measured GNP has to be augmented by the flow of services from government capital.

${ }^{15} \mathrm{On}$ the other hand, if one adopts a broad definition of government debt including both explicit and implicit government debt our ratio of government debt to GDP of 163 percent corresponds very well to the figure found in the data as documented by Fetzer, Moog, and Raffelhüschen (2002) using the method of Generational Accounting. These authors find that the sustainability gap, defined as the sum of explicit and implicit government debt, amounts to 162 percent of GDP in the base year 1999 .
} 
Production To calibrate the capital income share $\alpha$ we followed the procedure outlined in Cooley and Prescott (1995). Thereby our definition of the economy's capital stock includes fixed private capital and the government's capital stock. Accordingly we also augment measured GNP to include the flow of services from government capital. Corresponding to the average over the period 1980-2000 we choose a capital income share of $\alpha=.36$. The depreciation rate of the overall capital stock is calibrated to generate a ratio of investment to capital stock of approximately .0745 in the initial steady state, which corresponds to the average over the period 1980-2000. This is ensured by setting the depreciation rate $\delta$ equal to .051. Finally, as the average growth rate of GNP per capita over the period 1980-2000 amounted to 2.09 percent the growth rate of labor productivity $\gamma$ is set equal to .0209 .

\section{The German Income Tax Reform}

\subsection{Issues and Instruments}

With the adoption of the Tax Reduction Act by the German Bundestag, on July 6, 2000 and its approval by the Bundesrat, which represents the German states (Bundesländer), the German Tax Reform was passed into law by January 2001. Among other, one central element of the latest German Tax Reform is the GITR. As originally outlined the GITR implied a reduction of income tax rates to be implemented over time in a series of three stages as of 2001, 2003 and 2005.

In the first stage of the GITR, started on January 1, 2001, the basic income tax rate has fallen to 19.9 percent, the top rate was cut from 51 to 48.5 percent while the basic personal allowance was increased by EUR 494 to approximately EUR 7,206. ${ }^{16}$ During the second stage, which should have been started on January 1, 2003 the basic personal allowance would have been increased to EUR 7,426, the basic tax rate cut to 17 percent and the top rate fallen to 47 percent. But, as already outlined in the introduction the German government decided in the aftermath of the floodings of the Elbe river in summer 2002, with agreement of the oppositional conservative party, to postpone the already announced second stage of the GITR to January 1, 2004 in order finance the compensation payments to affected individuals and firms for their losses incurred. Finally, as from January 1, 2005 it was planned to put the third stage into place, which would have increased the basic personal allowance to EUR 7,664, while the basic tax rate would have been reduced to 15 percent and the top rate brought down to 42 percent. However, as a means of stimulating the stagnating German economy, the political decision makers agreed on a compromise, according to which the last stage of the GITR is partly brought forward to January 1, 2004 and thus set

\footnotetext{
${ }^{16}$ The first stage of the German Tax Reform was in fact the third stage of the Tax Relief Act 1999/2000/2002, with the 2002 stage brought forward by one year to January 1, 2001.
} 
into place together with the postponed second stage of the GITR, while the remainder of the third stage will follow on January 1, 2005.

In the following simulations we consider only a stylized version of the GITR. Specifically we do not consider the series of tax reforms corresponding to the three stages of the GITR. Instead we assume that all stages of the GITR are implemented at once at the date of implementation of the third stage of the GITR. Thereby, our status quo scenario corresponds to the legal status quo as of the year 2000. Accordingly the timing in our model is as follows. In 2000 (model period $t=0$ ) the economy is on its initial balanced growth path. Corresponding to the implementation of the first stage of the GITR in $2001(t=1)$ the tax reform in our model is announced to be implemented in $2005(t=5)$. In the 'early tax reform' scenario we concentrate on the actual status quo where the tax reform is brought forward by one year to $2004(t=4)$. Thereby, this change in the government's policy is announced in the year $2003(t=3)$.

Because of the GITR average income tax rates will fall on average by approximately 4 percentage points after the implementation of the final stage. However, as the average income tax rate overstates the effective income tax rate employed in the process of calibration we assume that income tax rates will fall by only 2 percentage points. ${ }^{17}$ Thus, in all of our simulations we lower the income tax rate by this amount, setting $\tau_{y}$ equal to .157 after the tax reform is implemented.

Finally, as was already noted in previous sections, the cut in income tax rates is accompanied by a countervailing cut in government transfer payments in future periods to restore intertemporal budget balance. Specifically, as of some period $\bar{t}$ the lump sum tax is specified such that the level of government debt (adjusted for productivity and population growth) remains constant until the economy reaches its new long run balanced growth path. The countervailing change in fiscal policy thus specified, it remains to specify the date $\bar{t}$ at which it will be implemented. Corresponding to the year 2005 we decided to set $\bar{t}$ equal to 5 in our simulations. This choice of $\bar{t}$ reflects the government's original plan to finance the tax reform without incurring further debt. Hence, in the status quo scenario the government holds the level of government debt constant after the implementation of the tax reform, thereby allowing the ratio of government debt to GDP to change until the new balanced growth path is reached. On the other hand, together with the decision to bringing forward the tax reform by one year the political decision makers agreed on partially financing this fiscal policy step by issuing further debt. Therefore, in the early tax reform scenario the level of government debt is allowed to change for one period and hold constant thereafter.

\footnotetext{
${ }^{17}$ Note that Martinez-Mongay (2000) provide an estimate of the effective income tax rate in the year 2001 which amounts to 15.9 percent. Hence, assuming that the effective income tax rate will fall by only 2 percentage points after the implementation of all three stages may indeed understate the true drop in effective income tax rates.
} 


\subsection{Results}

The Status Quo Scenario The results of our simulations are presented in Table $3 .^{18}$ Consider first the macroeconomic effects in the status quo scenario. Compared to the initial balanced growth path (henceforth abbreviated BGP) the capital stock is higher for all periods after the announcement of the reform as can be seen from the line labelled $K^{S Q}$. Moreover, the capital stock increases steadily along the transition path, resulting in a long run increase of 4.3 percent. Considering effective labor supply we see from the line labelled $N^{S Q}$ that effective labor supply is always larger, slightly increasing in the first periods after the announcement, overshooting its long run value as of the period of the implementation of the tax reform and declining thereafter to result in a 1.6 percent increase in the long run. This said, it is clear that output is always higher along the transition path, resulting in a long run rise of 2.6 percent as can be seen from the line labelled $Y^{S Q}$.

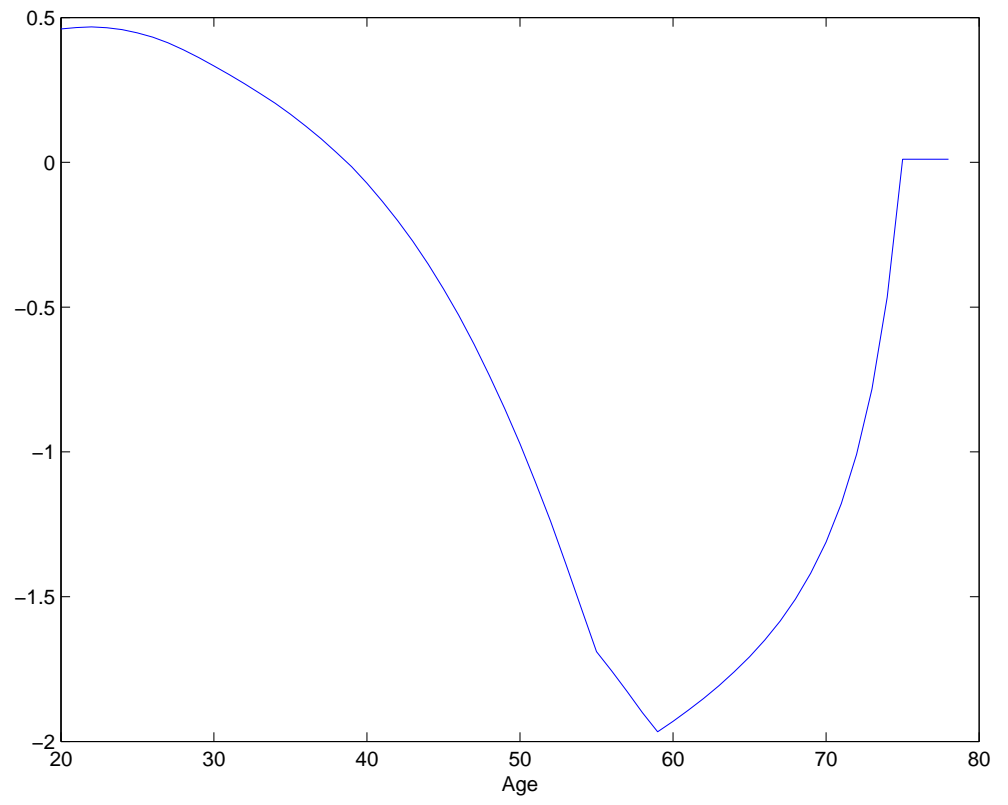

Figure 2: Percentage change in the age distribution of life-cycle resources after the announcement of the tax reform in period $t=1$

Next, consider the effects on consumption. In a model with an infinitely living representative agent one would expect consumption to rise as a result of the positive wealth effect induced by the future decline in

\footnotetext{
${ }^{18}$ If not otherwise stated the percentage changes mentioned in the following correspond to the deviations from the initial balanced growth path.
} 


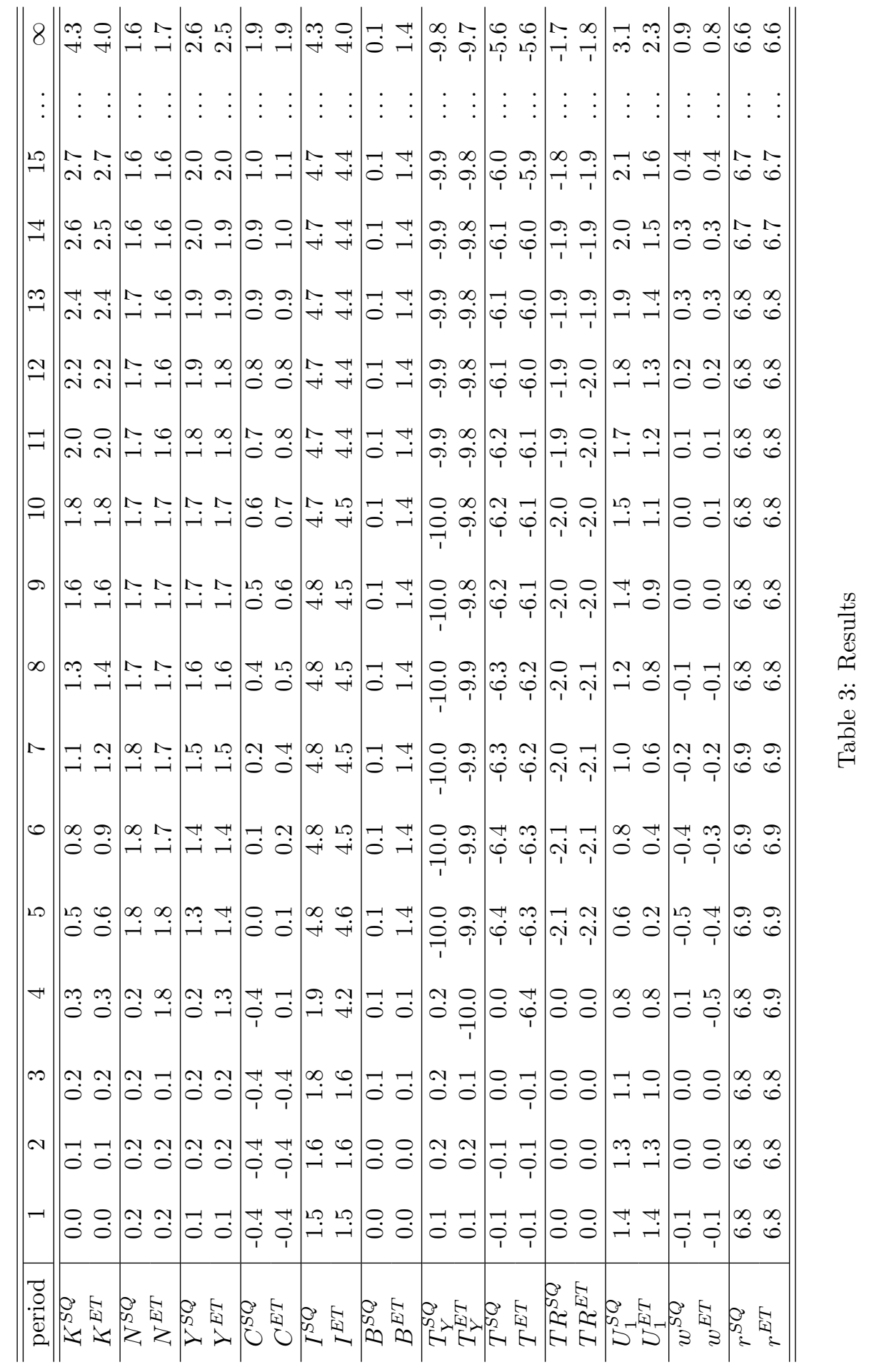




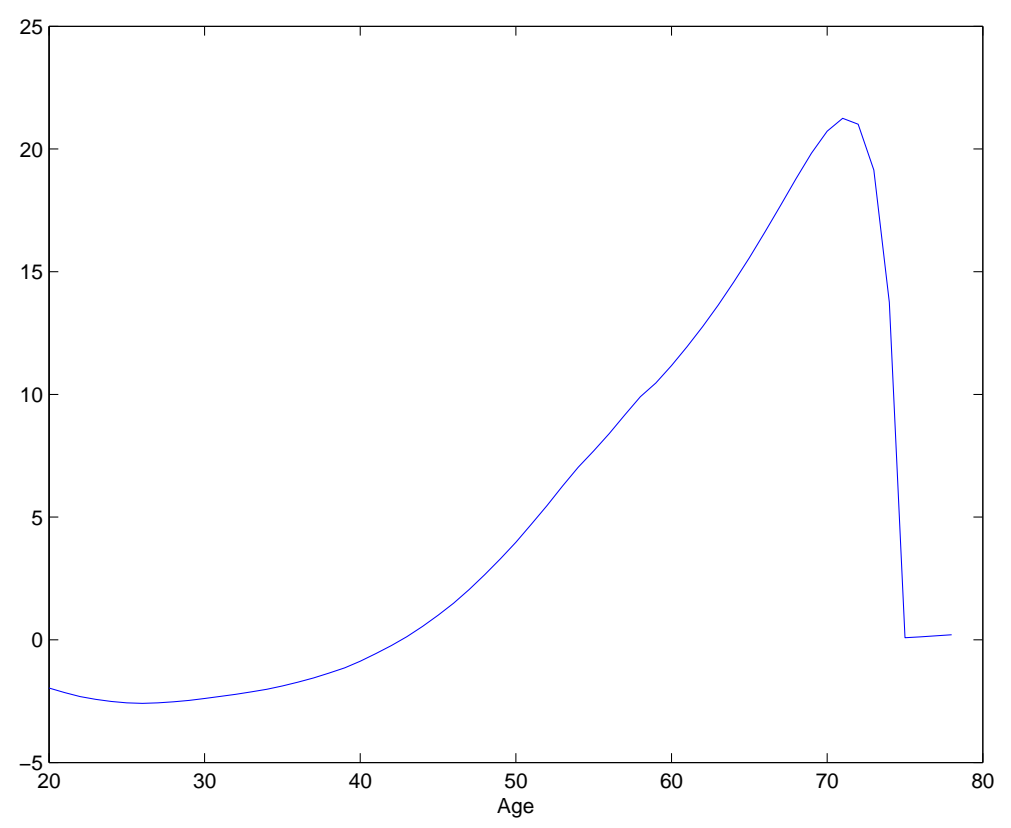

Figure 3: Percentage change in the age distribution of life-cycle tax liabilities after the announcement of the tax reform in period $t=1$

income tax rates. Contrary to this consumption declines following the announcement of the tax reform in our simulation as can be seen from the line labelled $C^{S Q}$. This is a consequence of the overlapping generations structure of our model. As can be seen from Figure 2, which depicts the percentage change in the age distribution of life-cycle resources as of period $t=1$, the young generations up to age 38 benefit in terms of life-cycle resources. On the other hand, the middle and old aged between age 39 and 74 lose in terms of life-cycle resources, while the very old are virtually not affected. This pattern can be explained by the fact that the lump sum tax imposed to balance the intertemporal budget is distributed equally on all living generations and to a lesser extent by the differing supply of efficiency units over the life-cycle. Specifically, as the lump sum tax substitutes for both the distorting tax on capital and labor income the benefits of the tax reform are unequally distributed because only individuals up to age 59 work at all, while the cost of the tax reform, i.e. the lump sum tax imposed, are equally distributed on all individuals. This unequal distribution of the benefits and costs of the tax reform in terms of tax liabilities is evident from Figure 3 which depicts the percentage change in the age distribution of tax liabilities as of period $t=1$. Hence, the middle and old aged individuals benefit only partially from the reduced income tax rates but have to fully contribute for the financing of the tax reform. Moreover, as a result of lower wages 
up to period $t=8$ all working age generations initially lose. But for the young generations this loss in labor income is not that serious as they supply only a small amount of efficiency units, while, being at the beginning of their life--cycle, they benefit much from the future rise in wages which hits them when they are near the maximum of the efficiency units profile. For the same reasons the middle aged older than 39 are initially hurt the most as their loss of labor income due to declining wages is magnified because they supply to a greater or lesser extent the maximum of efficiency units, while on the other hand benefitting only to a lesser extent from the future rise in wages which hits them when they are on the declining branch of the efficiency units profile or already retired. Hence, as the majority of living generations lose in terms of life-cycle resources it should be clear why consumption declines initially, while steadily rising after the tax reform is implemented to result in an long run increase of 1.9 percent. ${ }^{19}$

As savings are the mirror image of consumption, savings and therefore investment in our economy rise initially as can be seen from the line labelled $I^{S Q}$, thereby providing the funds needed to build up the higher capital stock. Besides the drop in consumption, investment rises as a result of the increasing output. Thereby, the fact that investment's share on GDP amounts to only 22.5 percent along the initial BGP explains the comparatively large reaction of investment. Like efficient labor supply investment rises steadily in the following periods, overshooting its long run value as of the moment when the tax reform is implemented and declining thereafter to result in a long run increase of 4.3 percent which needless to say is equal to the long run increase in the capital stock.

Next, consider the effects on government debt and tax revenue. As was already pointed out output rises while consumption initially declines. Therefore government's revenue from consumption taxation declines, while revenue from income taxation rises as is evident from the line labelled $T_{Y}^{S Q}$. Taken both components together we see from the line labelled $T^{S Q}$ that tax revenues initially decline thereby inducing a higher budget deficit which must be financed by accumulating additional debt. Hence, government debt merely rises as a result of the announcement of the tax reform. Because of our rule to balance the government's intertemporal budget this slightly higher level of government debt is maintained until the economy reaches its new BGP along which government debt is 0.1 percent higher than along the initial BGP. Note however, that the ratio of government debt to GDP falls by approximately 2.5 percent in the long run, which can be

\footnotetext{
${ }^{19}$ Note that there is also a substitution effect present as the net interest rate increases initially as a result of the slight increase in the before-tax interest rate and later on as a result of the decline in the income tax rate. Hence, as this rise in the net interest rate reduces the relative price of future consumption individuals substitute present for future consumption thereby contributing to the initial decline and later rise in consumption.
} 
seen from subtracting the percentage change in government debt from the percentage change in output. Of course, holding the level of government debt constant was achieved by raising additional revenue through the imposition of a lump sum tax or as we interpret it, by a corresponding reduction in government transfers. As can be seen from the line labelled $T R^{S Q}$, which contrary to the other variables considered expresses the cut in transfers as a share of GDP along the initial BGP, transfers must be cut by 2.1 percentage points as of the period when the tax reform is implemented. But as output and consumption increase in the following so does revenue from both consumption and income taxation. Hence, the share by which transfers must be cut declines following the implementation period to result in a long run cut of 1.7 percentage points. As the share of government transfer payments on GDP amounted to approximately 31.8 percent in 2000 cutting transfers by 1.7 percentage points implies bringing the share of government transfers moderately down to the value at the beginning of the 1990s.

Finally, the ultimate criterion for the evaluation of a fiscal policy change is its effect on the welfare of the individuals. Because of the individual heterogeneity present in an overlapping generations model there will be winners and losers of the tax reform proposal as we have already seen above. Thus welfare judgements based on the Pareto criterion are impossible. Therefore we consider as a first step the implications of the considered tax reform proposal on the welfare of the respective newborn individual in each period which can be read off the line labelled $U_{1}^{S Q}$. As can be seen the welfare of a newborn individual in period $t=1$ rises on impact by 1.4 percent, declining thereafter for the respective newborn in this period and beginning to rise again as of the moment when the tax reform is implemented to result in a long run welfare gain of 3.1 percent. Hence, in terms of its long run welfare implications the considered tax reform proposal is a good thing to do.

The Early Tax Reform Scenario As we have already discussed the results for our status quo scenario we are now prepared to compare these results to the case where the tax reform is brought forward by one year. As this fiscal policy step is first announced in period $t=3$ the transition path in the early tax reform scenario merely replicates the transition path in the status quo scenario for periods $t=1$ and $t=2$. Starting with the announcement of bringing the tax reform forward in period $t=3$ the transition paths in the two scenarios evolve differently. Comparing the lines superscripted ${ }^{S Q}$ and ${ }^{E T}$ in Table 3 one sees that on impact the macroeconomic effects of the tax reform are to a greater or lesser extent merely 
brought forward by one year. However, taking a glance on the long run impacts of the tax reform under the two scenarios one sees from comparing the lines labelled $B^{E T}$ and $B^{S Q}$ that government debt rises by 1.4 percent in the early tax reform scenario compared to only .1 percent in the status quo scenario. But as the decision to bring forward the tax reform was accompanied by the decision to fund this fiscal policy step through the additional accumulation of debt this difference should come as no surprise. However, this difference in the evolution of government debt is the key for the explanation of the slight variations in the evolution of the other macroeconomic aggregates. As the government draws on the resources provided by the private sector to fund the higher level of government debt private investment is partially crowded out, resulting in a slightly lower increase of both investment and the capital stock. However, as the higher level of government debt implies a slightly larger cut in transfers necessary to balance the government's intertemporal budget in the long run this effect is partially compensated for by a slightly larger rise in effective labor supply so that output is only .1 percentage points smaller in the long run. Moreover, as a smaller capital stock demands only a lower level of investment consumption is virtually not affected. The same is true for tax revenues which as a result of a negligible effect on revenues from consumption taxation are virtually not affected despite the fact that revenues from income taxation are lower by 0.1 percentage points. Nonetheless, comparing the lines labelled $U_{1}^{E T}$ and $U_{1}^{S Q}$ one sees that the long run welfare impact of bringing the tax reform forward amounts to only 2.3 percent and is thus .8 percentage points lower as in the status quo scenario, which is mainly a result of the negative welfare effect induced by the rise in individual labor supply or expressed in different words a result of the lower consumption of leisure. Hence, judged by its long run welfare implications bringing forward the tax reform by one year was a bad thing to do. On the other hand, as the political decision makers aimed at stimulating the 'stuttering engine' of the economy by bringing forward the tax reform our results can be interpreted as a confirmation of these expectations. However, at least in our model this growth impulse is independent of whether the tax reform is financed by a cut in transfer payments or by accumulating debt. Thus, the decision to fund the earlier tax reform by accumulating further debt implies that the cost of the tax reform are to a greater extent distributed towards the future generations. On the other hand, as was shown above, the middle and old aged generations are the losers of the tax reform proposal so that bringing the tax reform forward may be seen as a means of distributing the costs of the tax reform more evenly across present and future 
generations. ${ }^{20}$ All in all the future generations still gain a non-negligible 2.3 percent in terms of utility.

\subsection{Social Welfare Analysis and Political Economy Aspects of Bringing For- ward a Tax Reform}

In the preceding subsection we already touched on welfare issues by considering the effects of our tax reform scenarios on the welfare of newborn individuals. In this subsection we adopt a social welfare perspective as an additional welfare criterion. Thereby we assume a standard utilitarian social welfare function by simply summing up the utility indices of all presently living and future generations over their remaining life-time. As this summation reaches into the infinite future we have to discount the utility indices of future generations. Specifically, the assumed social discount factor $\beta_{\text {soc }}$ is set on a value of 0.99. ${ }^{21}$ Moreover, besides the social welfare analysis we touch the political economy aspects of our tax reform scenarios by asking the question which reform scenario might win a majority vote. Thereby we assume that an individual will vote for the option under which it reaches the higher welfare level.

The results of the social welfare analysis are presented in Table 4. First we ask whether the GITR should have been adopted at all by comparing our status quo scenario against the initial BGP. As the tax reform in the status quo scenario is announced in model period $t=1$, this is the relevant comparison period in this case. As can be seen from the first line of Table 4 adopting the GITR was the right thing to do in terms of social welfare. This is not that surprising as we already saw in the preceding subsection that the tax reform is accompanied by a non-negligible positive welfare effect in the long run. Next, we ask whether the tax reform should have been brought forward by comparing our status quo scenario against the early tax reform scenario. Thereby model period $t=3$ is the relevant comparison period as the fiscal policy option to bring forward the tax reform is announced in period $t=3$. Now, as can be seen from the second line of Table 4 bringing forward the tax reform was a bad thing to do judged by its social welfare implications. Once more, this result shouldn't come as a surprise as the status quo scenario already outperformed the early tax reform scenario in terms of its long run welfare impact.

As already mentioned above we next adopt a political economy perspective by asking whether a tax reform option will win a majority vote against the option of remaining on the current growth path. The results

\footnotetext{
${ }^{20}$ However, note that Germany's current fiscal policy already implies a substantial amount of intergenerational redistribution at the expense of future generations as documented by Ehrentraut and Raffelhüschen (2003) using the method of Generational Accounting.

${ }^{21}$ In accordance with the transformation of our economy described above the social discount rate has to be transformed as well. The social discount rate in our transformed economy is then given by $\beta_{\text {soc }}^{*}=\beta_{\text {soc }}(1+\eta)(1+\gamma)^{\phi(1-\rho)}$.
} 


\begin{tabular}{c|ccc}
\hline \hline Comparison Period & initial BGP & Status Quo & Early Tax Reform \\
\hline \hline 1 & 2748.0 & $\mathbf{2 7 5 6 . 8}$ & \\
3 & & $\mathbf{2 6 8 9 . 5}$ & 2686.5 \\
\hline \hline
\end{tabular}

Table 4: Social Welfare Analysis

\begin{tabular}{c|ccc}
\hline \hline Comparison Period & initial BGP & Status Quo & Early Tax Reform \\
\hline \hline 1 & $\mathbf{6 2}$ & 38 & \\
3 & & 3 & $\mathbf{9 7}$ \\
\hline \hline
\end{tabular}

Table 5: Political Economy Results

of this political economy experiment are presented in Table 5. Once more we first consider the question whether the GITR should have been adopted at all if judged against the option of remaining on the initial BGP. As can be seen from the first line of Table 5 in the scope of our model the GITR proposal wouldn't been adopted if the individuals where given the possibility of a vote. Specifically only 38 percent of the electorate would vote for the GITR, while the remaining 62 percent would vote for the option of remaining on the initial BGP despite the fact that the former outperforms the latter in terms of its long run welfare impact. This result is driven by the already mentioned fact that only the young generations win by the adoption of the GITR, while the mass of the old and middle aged generations lose because as a matter of fact these generations reap only part of the benefits of the lower taxation of labor income while at the same time have to fully contribute for the funding of the tax reform through the lump sum tax imposed uniformly on all living generations (See Figures 2 and 3).

On the other hand, assuming that the GITR was adopted initially in period $t=1$ we see from the second line in Table 5 that the option of bringing the tax reform forward by one year will win a majority vote against the option to remain on the transition path pursued by the initial adoption of the GITR. Specifically, an overwhelming share of 97 percent of the electorate would vote in favor of bringing the tax reform forward by one year, while only 3 percent would like to stay on the road pursued by the initial adoption of the GITR. Once more this result is driven by the middle aged who in principal oppose the adoption of the GITR at all but on the other hand prefer having the tax reform implemented at a date as early as possible to benefit as much as possible from the lower income tax rate, while their contribution towards expenses remains almost the same because bringing forward the tax reform is financed by accumulating government debt. 


\subsection{Sensitivity}

In the following subsection we consider the sensitivity of our results with respect to some of the key parameters of our model. Thereby we concentrate on the differences with respect to the long run impact on the major macroeconomic aggregates. The results of our sensitivity analysis are presented in Table 6 . First we consider the sensitivity with respect to the discount factor $\beta$. As can be seen from column 2 setting $\beta$ on a lower value of 0.99 has only minor consequences for the long run impact on the macroeconomic aggregates. But as a lower $\beta$ implies that individuals become more impatient the long run change in welfare is less than one fourth of the one in our benchmark calibration. The same holds for the case $\phi=0.2$ in column 3, which implies a more elastic supply of labor. Although the long run impact on capital, effective labor supply, output and consumption is slightly larger, while the impact on government debt in our early tax reform scenario is slightly smaller, the long run welfare change is approximately cut in half compared to our benchmark. But as labor supply increases this comes as no surprise as $\phi=0.2$ implies a larger weight of leisure in our subutility index which is made up of consumption and leisure.

Next we consider the case $\phi=1$, which implies that labor is inelastically supplied. In this case the long run impact on the macroeconomic aggregates is considerably smaller as can be seen from column 4 . In particular, compared to all other cases our two scenarios differ considerably with respect to their long run impact. This is a result of the fact that in the case of an inelastic labor supply individuals are less flexible in responding to a change in fiscal policy. Specifically, in the case of an inelastic labor supply individuals are less willing to increase their amount of savings, as this implies a corresponding drop in present consumption. Contrary to this, in our benchmark calibration this drop in consumption levels is partially compensated for by an increase in labor supply. Because of this lower willingness to save in the case of an inelastic labor supply the effect of an increase in government debt on private investment is magnified compared to our benchmark calibration, which explains the differences between our tax reform scenarios in this case. Moreover, as one can see from the last two lines it no longer holds that the tax reform is accompanied by a long run welfare gain in our status quo scenario, while actually resulting in a welfare loss in the early tax reform scenario. ${ }^{22}$

Next, the sensitivity of our results with respect to the intertemporal elasticity of substitution $1 / \rho$ can be

\footnotetext{
${ }^{22}$ These results stress the importance of allowing for an elastic labor supply in performing an analysis of tax policy in
} dynamic general equilibrium models. We thank an anonymous referee for pointing this out to us. 


\begin{tabular}{l|cccccccc}
\hline \hline & Benchmark & $\beta=.99$ & $\phi=.2$ & $\phi=1$ & $\rho=1$ & $\rho=5$ & $\Delta \tau_{y}=-.04$ & $\bar{t}=10$ \\
\hline \hline$K^{S Q}$ & 4.3 & 4.2 & 4.6 & 2.2 & 3.0 & 4.2 & 8.4 & 2.5 \\
$K^{E T}$ & 4.0 & 4.0 & 4.3 & 0.9 & 2.8 & 3.7 & 7.7 & 2.2 \\
\hline$N^{S Q}$ & 1.6 & 1.7 & 1.9 & 0.0 & 1.3 & 1.6 & 3.2 & 1.8 \\
$N^{E T}$ & 1.7 & 1.7 & 1.9 & 0.0 & 1.3 & 1.7 & 3.2 & 1.8 \\
\hline$Y^{S Q}$ & 2.6 & 2.6 & 2.8 & 0.8 & 1.9 & 2.5 & 5.0 & 2.0 \\
$Y^{E T}$ & 2.5 & 2.5 & 2.8 & 0.3 & 1.8 & 2.4 & 4.8 & 1.9 \\
\hline$C^{S Q}$ & 1.9 & 2.1 & 2.1 & 0.5 & 0.9 & 2.1 & 3.7 & 1.8 \\
$C^{E T}$ & 1.9 & 2.1 & 2.1 & 0.2 & 0.9 & 2.0 & 3.7 & 1.8 \\
\hline$B^{S Q}$ & 0.1 & 0.1 & 0.1 & 0.1 & 0.4 & 0.1 & 0.2 & 6.5 \\
$B^{E T}$ & 1.4 & 1.8 & 1.1 & 2.3 & 2.6 & 1.8 & 2.7 & 7.9 \\
\hline$T^{S Q}$ & -5.6 & -5.4 & -5.6 & -6.8 & -6.2 & -5.4 & -11.6 & -5.3 \\
$T^{E T}$ & -5.6 & -5.3 & -5.5 & -6.8 & -6.2 & -5.3 & -11.5 & -5.2 \\
\hline$T R^{S Q}$ & -1.7 & -1.7 & -1.6 & -1.9 & -1.6 & -1.7 & -3.4 & -2.1 \\
$T R^{E T}$ & -1.8 & -1.8 & -1.7 & -2.1 & -1.6 & -1.9 & -3.6 & -2.3 \\
\hline$U_{1}^{S Q}$ & 3.1 & 0.7 & 1.4 & 0.0 & -0.3 & 16.6 & 5.5 & -1.1 \\
$U_{1}^{E T}$ & 2.3 & 0.5 & 1.1 & -0.2 & -0.3 & 9.2 & 4.1 & -2.0 \\
\hline \hline
\end{tabular}

Table 6: Sensitivity Analysis

read off columns 5 and 6 of Table 6 . Considering first the case $\rho=1$, which corresponds to the case of a logarithmic utility function, we see that the impact on capital, labor supply, output and consumption are dampened compared to the benchmark, while the impacts on government debt and tax revenue are magnified. This is simply explained by the fact, that a higher intertemporal elasticity of substitution implies that individuals are more disposed to postpone consumption as present and future consumption are better substitutes. But this implies that savings respond only to a lesser extent on changes in tax rates as the individuals propensity to save is already high. Therefore, as in the case of an inelastic labor supply the lower willingness to increase savings means that government debt crowds out a larger fraction of private investment, resulting in a dampened effect on long run capital accumulation. Moreover, considering the welfare impact we see that both tax reform scenarios result in a welfare loss of equal magnitude. Considering then the case $\rho=5$ in column 6 the most notable difference compared to the benchmark is the substantially magnified long run welfare impact. On the other hand, while the impact on the macroeconomic aggregates differ only slightly taking all considered cases, i.e. $\rho=1,3.33$ and 5 , together reveals a hump-shaped relationship with respect to the long run impact on the major macroeconomic aggregates.

Finally, we consider the sensitivity of our results with respect to the design of the tax reform proposal. 


\begin{tabular}{c|ccc}
\hline \hline & initial BGP & Status Quo & Early Tax Reform \\
\hline \hline \multirow{2}{*}{ Benchmark } & 2748.0 & $\mathbf{2 7 5 6 . 8}$ & \\
& & $\mathbf{2 6 8 9 . 5}$ & 2686.5 \\
$\beta=.99$ & 3955.2 & $\mathbf{3 9 6 3 . 4}$ & \\
& & $\mathbf{3 8 6 6 . 3}$ & 3863.1 \\
$\phi=.2$ & 2946.4 & $\mathbf{2 9 5 1 . 4}$ & \\
& & $\mathbf{2 9 0 9 . 8}$ & 2908.2 \\
$\phi=1$ & 4575.2 & $\mathbf{4 5 7 6 . 2}$ & \\
& & $\mathbf{4 1 7 6 . 1}$ & 4174.9 \\
$\rho=1$ & $\mathbf{8 6 7 1 . 8}$ & 8648.7 & \\
& & 8692.1 & $\mathbf{8 6 9 8 . 8}$ \\
& 2416.2 & $\mathbf{2 4 3 1 . 6}$ & \\
$\Delta \tau_{y}=-.04$ & 2748.0 & $\mathbf{2 3 2 2 . 5}$ & 2316.0 \\
$\bar{t}$ & & $\mathbf{2 7 6 3 . 3}$ & \\
& 2748.0 & $\mathbf{2 6 9 6 . 4}$ & 2690.8 \\
\hline \hline
\end{tabular}

Table 7: Sensitivity of Social Welfare Results

First we consider the case of a larger drop in income tax rates. As was already mentioned in footnote 17, our assumption that income tax rates fall by 2 percentage points may indeed understate the true drop in effective income tax rates. Taking a glance at column 7 we see that the impact on the macroeconomic aggregates approximately doubles if we cut tax rates by 4 percentage points. Second, by setting $\bar{t}=10$ we allow the level of government debt to change until 2010. Indeed, as Germany not only failed to pass the Maastricht criteria in the last years but may do so for the years to come one might regard this assumption as the more realistic case. Taking a glance at the last column one sees that such a policy implies a considerable rise in government debt compared to the benchmark, which demands a larger cut in transfers and halves the tax reform's impact on capital accumulation. All in all this results in a welfare loss in both scenarios and implies a considerable amount of intergenerational redistribution in favor of present generations. As already pointed out by Summers (1981) and subsequent authors this last result stresses that the welfare gains of any tax reform stem from its impact on the process of capital accumulation, including both physical and human capital. Hence, based on these results one can only hope that the coalition of the Social Democrats and the Greens retrieves back on the road of sound public finance which they promised to pursue when they overtook the government business some years ago.

Finally, Tables 7 and 8 summarize the sensitivity of our social welfare and political economy results with respect to the considered parameter variations. As is evident from Table 7 compared to our benchmark 


\begin{tabular}{c|ccc}
\hline \hline & initial BGP & Status Quo & Early Tax Reform \\
\hline \hline \multirow{2}{*}{ Benchmark } & $\mathbf{6 2}$ & 38 & \\
& & 3 & $\mathbf{9 7}$ \\
$\beta=.99$ & $\mathbf{5 5}$ & 45 & \\
& & 11 & $\mathbf{8 9}$ \\
$\phi=.2$ & $\mathbf{7 0}$ & 30 & \\
& & 2 & $\mathbf{9 8}$ \\
$\phi=1$ & 49 & $\mathbf{5 1}$ & \\
& & 13 & $\mathbf{8 7}$ \\
$\rho=1$ & $\mathbf{1 0 0}$ & 0 & $\mathbf{1 0 0}$ \\
$\rho=5$ & & 0 & \\
& $\mathbf{5 3}$ & 47 & $\mathbf{8 9}$ \\
$\Delta \tau_{y}=-.04$ & $\mathbf{6 2}$ & 38 & $\mathbf{6 4}$ \\
$\bar{t}=10$ & 37 & 36 & $\mathbf{6 3}$ \\
& & 2 & $\mathbf{9 8}$ \\
\hline \hline
\end{tabular}

Table 8: Sensitivity of Political Economy Results

calibration the results of the social welfare analysis differ only in the case of $\rho=1$, where both tax reform scenarios are accompanied by a long run welfare loss. In all other cases the qualitative findings are unaltered. Next, concerning our analysis of the political economy aspects Table 8 reveals that bringing forward the tax reform is always the policy preferred by a majority of individuals as was already the case in our benchmark calibration. On the other hand, in the cases $\phi=1$ and $\bar{t}=10$ the option of implementing the tax reform at all, i.e. our status quo scenario, is now preferred by a majority of voters as opposed to the option of remaining on the initial BGP.

\section{Conclusions}

The latest GITR relieves present and future generations from part of their burden by reducing income tax rates in a series of three stages, which will be finished by January 1, 2005. The present paper focused on the welfare and macroeconomic effects of this fiscal policy step in the scope of a closed economy overlapping generations model encompassing 59 generations and an endogenous labor supply decision. In particular, we quantified the welfare and macroeconomic consequences induced by the decision to bring the third and latest stage of the GITR partly forward to January 1, 2004.

As originally outlined the German government planned to finance the drop in income tax rates without 
incurring further debt. Therefore we assumed that the level of government debt, adjusted for population and productivity growth, will remain constant as of the date of implementation of the tax reform. Our results for this case indicate that the GITR will be accompanied by a boost in capital accumulation which results in a capital stock 4.3 percent higher than along the initial balanced growth path, while effective labor supply will rise by 1.6 percent. All in all, this amounts to a long run increase in GDP of 2.6 percent which reflects itself in a long run welfare gain of 3.1 percent for future generations.

Contrary to the original outline, the decision to bring forward the latest stage of the GITR was accompanied by the decision to partly finance this fiscal policy step by incurring further government debt. As a higher level of government debt implies that future generations are more heavily burdened it comes as no surprise that the long run welfare gain is reduced but still amounts to 2.3 percent. On the other hand, the differences in terms of the macroeconomic effects are less pronounced. Thus, the decision to bring forward the tax reform was a bad thing to do if judged by its long run welfare implications.

For this reason, the decision to stick with the original plan is also the preferred policy if judged by its social welfare implications, as the long run welfare gains outweigh the short and medium run welfare gains of present generations induced by bringing forward the tax reform. However, adopting a political economy view on the subject we asked whether a tax reform option will win a majority vote against the option of staying on the pursued growth path. At least in the scope of our model the results on this issue indicate that the GITR would not have won a majority vote, while if being implemented the option to bring forward the GITR is the policy preferred by a majority of voters.

However, the decision to fund the earlier tax reform by accumulating further debt implies that the cost of the tax reform are to a greater extent distributed towards the future generations. On the other hand, as the presently living middle and old aged generations are the losers of the original tax reform proposal bringing the tax reform forward may be seen as a means of distributing the costs of the tax reform more evenly across present and future generations. This result holds even if one takes into account the fact that Germany's current fiscal policy already implies a substantial amount of intergenerational redistribution at the expense of future generations as they still gain a non-negligible 2.3 percent in terms of utility.

Finally, at least one caveat regarding our positive evaluation of the GITR should be mentioned. Namely the assumption that the government holds constant the level of debt, which at least in our simulations resulted in a declining ratio of government debt to GDP. Remember from our discussion that the differences 
between the considered scenarios arise merely because in the 'early tax reform' we allowed government debt to rise for one period following the implementation of the tax reform, which resulted in a higher long run level of government debt compared to our status quo scenario. Also, as shown in the scope of our sensitivity analysis, if the decline in tax revenue following the tax reform is at least partially offset by incurring further government debt the long run impact on capital accumulation and welfare gain declines and in the case considered resulted in a long run welfare loss. Hence, the long run welfare gain which we documented hinges on our assumption that the government holds constant the level of government debt. However, despite politician's announcements to balance the budget and to bring down the level of government debt until today only little has been done in this direction. Therefore, our assumption may be regarded as unrealistically optimistic, implying that the German Income Tax Reform may indeed be accompanied by a welfare loss for future generations and a corresponding larger welfare gain for present generations. Hence, as a larger share of present generations experiences a welfare gain if one employs a less optimistic assumption about government's attitude towards incurring further debt, this may rationalize why the approval of the whole tax reform package in 2001 was welcomed by the public.

On the other hand, in the light of this discussion it may be the case that future generations are the losers of the tax reform package so that the GITR indeed burdens future generations despite the fact that they face lower income tax rates. Hence, as this may indeed be the more realistic case and based on the grounds of generational justice one can only hope that the German government retrieves back on the road of sound public finance which they promised to pursue when they overtook the government business some years ago. 


\section{A Simulation Methodology}

To solve the model numerically we employ value function iteration on a linear-quadratic approximation ( $L Q$ approximation) of the model about its initial steady state. As this approach is extensively discussed in the literature and well described in Hansen and Prescott (1995) and Ríos-Rull (1996) we only mention some issues special to the problem at hand.

First, in contrast to the application of value function iteration and LQ approximations in the business cycle literature we consider a macroeconomic environment which changes over time because of the considered tax reforms. Hence, the value and policy functions are in general not time-invariant but depend explicitly on time. On the other hand note, that the changes in the macroeconomic environment are finished as of the period when the government's budget is adjusted to restore intertemporal budget balance, i.e. as of model period $\bar{t}$. Afterwards the value and policy functions become time-invariant. Hence, we first iterate the value function until convergence to obtain the model's time-invariant solution valid for periods $t \geq \bar{t}$. The time-variant value and policy functions for periods $t<\bar{t}$ are then obtained by simple backward recursion starting from the respective time-invariant period $\bar{t}$ value functions.

Second, besides time the state of our economy consists of the economy-wide asset distribution and the level of government debt. While the law of motion to the former is endogenously determined as part of the solution, the law of motion to the latter is given by the government's budget constraint in (14) which is a non-linear function of the state. But as we employ a LQ approximation we can only deal with laws of motion which are linear functions of the state. Hence, to incorporate the law of motion for the level of government debt we use a linear approximation of the government's budget constraint about the initial steady state.

\section{References}

Aiyagari, S. R. (1995): "Optimal Capital Income Taxation with Incomplete Markets, Borrowing Constraints, and Constant Discounting," Journal of Political Economy, 103, 1158-1175.

Auerbach, A. J., and L. J. Kotlikoff (1987): Dynamic Fiscal Policy. Cambridge University Press, Cambridge. 
Boss, A. (2000): "Steuer- und Ausgabenpolitik in Deutschland," Discussion Paper 975, Institut für Weltwirtschaft, Kiel, Germany.

Carey, D., and H. TChilinguirian (2000): "Average effective tax rates on capital, labour and consumption," Discussion Paper 258, OECD Economics Department, Paris, France.

Chamley, C. (1986): "Optimal Taxation of Capital Income in General Equilibrium with Infinite Lives," Econometrica, 54, 607-622.

Cooley, T. F., and E. C. Prescott (1995): "Economic Growth and Business Cycles," in Frontiers of Business Cycle Research, ed. by T. F. Cooley. Princeton University Press, Princeton, NJ.

Diamond, P. A. (1965): "National Debt in a Neoclassical Growth Model," American Economic Review, $55,1126-1150$.

Ehrentraut, O., And B. Raffelhüschen (2003): "Die Rentenversicherung unter Reformdruck - Ein Drama in drei Akten," Wirtschaftsdienst, 83, 711-720.

Fetzer, S., S. Moog, And B. Raffelhüschen (2002): "Zur Nachhaltigkeit der Generationenverträge: Eine Diagnose der Kranken- und Pflegeversicherung," Zeitschrift für die gesamte Versicherungswissenschaft, 3/2002, 279-302.

Grüner, H. P., And B. Heer (2000): "Optimal flat-rate taxes on capital - a re-examination of Lucas' supply side model," Oxford Economic Papers, 52, 289-305.

Hansen, G. D., and E. C. Prescott (1995): "Recursive Methods for Computing Equilibria of Business Cycle Models," in Frontiers of Business Cycle Research, ed. by T. F. Cooley. Princeton University Press, Princeton, NJ.

HiRTe, G. (2002): "Welfare and Macroeconomic Effects of the German Pension Acts of 1992 and 1999 : A Dynamic CGE Study," German Economic Review, 3, 81-106.

Homburg, S. (2000): “German Tax Reform 2000: Description and Appraisal," Finanzarchiv, 57, 504-513.

Jones, L. E., R. E. Manuelli, and P. E. Rossi (1993): "Optimal Taxation in Models of Endogenous Growth," Journal of Political Economy, 101, 485-517. 
JudD, K. L. (1985): "Redistributive Taxation in a Simple Perfect Foresight Model," Journal of Public Economics, 28, 59-84.

Keen, M. (2002): “The German Tax Reform of 2000," International Tax and Public Finance, 9, 603-621.

King, R. G., C. I. Plosser, and S. Rebelo (1988): "Production, Growth and Business Cycles I: The Basic Neoclassical Model," Journal of Monetary Economics, 21, 195-232.

King, R. G., And S. Rebelo (1990): "Public Policy and Economic Growth: Developing Neoclassical Implications," Journal of Political Economy, 98, S126-S150.

Leibfritz, W., And M. SteinherR (1999): "Auswirkungen der Steuerreform auf die Wirtschaft," IFO Schnelldienst, 5/99, 16-21.

LuUngqvist, L., And T. J. SARgent (2000): Recursive Macroeconomic Theory. MIT Press, Cambridge, MA.

LucAs, JR., R. E. (1990): "Supply-Side Economics: An Analytical Review," Oxford Economic Papers, 42, 293-316.

Martinez-Mongay, C. (2000): "ECFIN's Effective tax rates. Properties and Comparisons with other tax indicators," Discussion Paper 146, Commission of the EC, Directorate-General for Economic and Financial Affairs (DG ECFIN), Brussels, Belgium.

Mendoza, E. G., A. Razin, and L. L. Tesar (1994): "Effective Tax Rates in Macroeconomics: CrossCountry Estimates of Tax Rates on Factor Incomes and Consumption," Journal of Monetary Economics, $34,297-323$.

Milesi-Ferretti, G. M., And N. Roubini (1998): "Growth Effects of Income and Consumption Taxes," Journal of Money, Credit and Banking, 30, 721-744.

Prescott, E. C., and R. Mehra (1980): "Recursive Competitive Equilbrium: The Case of Homogeneous Households," Econometrica, 48, 1365-1379.

Ríos-Rull, J.-V. (1996): "Life-Cycle Economies and Aggregate Fluctuations," Review of Economic Studies, 63, 465-489. 
SAmuelson, P. A. (1958): "An Exact Consumption-Loan Model of Interest with or without the Social Contrivance of Money," Journal of Political Economy, 66, 467-482.

Schreiber, U. (2000): "German Tax Reform - An International Perspective," Finanzarchiv, 57, 525-541.

Sinn, H.-W., And U. Scholten (1999): "Steuerreform, Kapitalkosten und Sozialprodukt," IFO Schnelldienst, 28/99, 14-18.

Sørensen, P. B. (2002): "The German Business Tax Reform of 2000: A General Equilibrium Analysis," German Economic Review, 3, 347-378.

Stokey, N., And S. Rebelo (1995): "Growth Effects of Flat-Rate Taxes," Journal of Political Economy, $103,519-550$.

Strulik, H. (2003): "Supply-Side Economics of Germany's Year 2000 Tax Reform: A Quantitative Assessment," German Economic Review, 4, 183-202.

Summers, L. H. (1981): "Capital Taxation and Accumulation in a Life Cycle Growth Model," American Economic Review, 71, 533-544.

VDR (2002): Rentenversicherung in Zeitreihen 2002, vol. 22 of DRV-Schriften. Verband deutscher Rentenversicherungsträger, Frankfurt am Main. 


\title{
CESifo Working Paper Series
}

\author{
(for full list see www.cesifo.de)
}

1245 Rafael Lalive and Alois Stutzer, Approval of Equal Rights and Gender Differences in Well-Being, July 2004

1246 Paolo M. Panteghini, Wide vs. Narrow Tax Bases under Optimal Investment Timing, July 2004

1247 Marika Karanassou, Hector Sala, and Dennis J. Snower, Unemployment in the European Union: Institutions, Prices, and Growth, July 2004

1248 Engin Dalgic and Ngo Van Long, Corrupt Local Government as Resource Farmers: The Helping Hand and the Grabbing Hand, July 2004

1249 Francesco Giavazzi and Guido Tabellini, Economic and Political Liberalizations, July 2004

1250 Yin-Wong Cheung and Jude Yuen, An Output Perspective on a Northeast Asia Currency Union, August 2004

1251 Ralf Elsas, Frank Heinemann, and Marcel Tyrell, Multiple but Asymmetric Bank Financing: The Case of Relationship Lending, August 2004

1252 Steinar Holden, Wage Formation under Low Inflation, August 2004

1253 Ngo Van Long and Gerhard Sorger, Insecure Property Rights and Growth: The Roles of Appropriation Costs, Wealth Effects, and Heterogeneity, August 2004

1254 Klaus Wälde and Pia Weiß, International Competition, Slim Firms and Wage Inequality, August 2004

1255 Jeremy S. S. Edwards and Alfons J. Weichenrieder, How Weak is the Weakest-Link Principle? On the Measurement of Firm Owners' Control Rights, August 2004

1256 Guido Tabellini, The Role of the State in Economic Development, August 2004

1257 François Larmande and Jean-Pierre Ponssard, EVA and the Controllability-congruence Trade-off: An Empirical Investigation, August 2004

1258 Vesa Kanniainen and Jenni Pääkkönen, Anonymous Money, Moral Sentiments and Welfare, August 2004

1259 Panu Poutvaara and Andreas Wagener, Why is the Public Sector More Labor-Intensive? A Distortionary Tax Argument, August 2004

1260 Lars P. Feld and Stefan Voigt, Making Judges Independent - Some Proposals Regarding the Judiciary, August 2004 
1261 Joop Hartog, Hans van Ophem, and Simona Maria Bajdechi, How Risky is Investment in Human Capital?, August 2004

1262 Thomas Eichner and Rüdiger Pethig, Efficient Nonanthropocentric Nature Protection, August 2004

1263 David-Jan Jansen and Jakob de Haan, Look Who's Talking: ECB Communication during the First Years of EMU, August 2004

1264 David F. Bradford, The X Tax in the World Economy, August 2004

1265 Hans-Werner Sinn, Migration, Social Standards and Replacement Incomes. How to Protect Low-income Workers in the Industrialized Countries against the Forces of Globalization and Market Integration, August 2004

1266 Wolfgang Leininger, Fending off one Means Fending off all: Evolutionary Stability in Submodular Games, August 2004

1267 Antoine Bommier and Bertrand Villeneuve, Risk Aversion and the Value of Risk to Life, September 2004

1268 Harrie A. A. Verbon and Lex Meijdam, Too Many Migrants, Too Few Services: A Model of Decision-making on Immigration and Integration with Cultural Distance, September 2004

1269 Thomas Eichner and Rüdiger Pethig, Economic Land Use, Ecosystem Services and Microfounded Species Dynamics, September 2004

1270 Federico Revelli, Performance Rating and Yardstick Competition in Social Service Provision, September 2004

1271 Gerhard O. Orosel and Klaus G. Zauner, Vertical Product Differentiation When Quality is Unobservable to Buyers, September 2004

1272 Christoph Böhringer, Stefan Boeters, and Michael Feil, Taxation and Unemployment: An Applied General Equilibrium Approach, September 2004

1273 Assaf Razin and Efraim Sadka, Welfare Migration: Is the Net Fiscal Burden a Good Measure of its Economics Impact on the Welfare of the Native-Born Population?, September 2004

1274 Tomer Blumkin and Volker Grossmann, Ideological Polarization, Sticky Information, and Policy Reforms, September 2004

1275 Katherine Baicker and Nora Gordon, The Effect of Mandated State Education Spending on Total Local Resources, September 2004

1276 Gabriel J. Felbermayr and Wilhelm Kohler, Exploring the Intensive and Extensive Margins of World Trade, September 2004 
1277 John Burbidge, Katherine Cuff and John Leach, Capital Tax Competition with Heterogeneous Firms and Agglomeration Effects, September 2004

1278 Joern-Steffen Pischke, Labor Market Institutions, Wages and Investment, September 2004

1279 Josef Falkinger and Volker Grossmann, Institutions and Development: The Interaction between Trade Regime and Political System, September 2004

1280 Paolo Surico, Inflation Targeting and Nonlinear Policy Rules: The Case of Asymmetric Preferences, September 2004

1281 Ayal Kimhi, Growth, Inequality and Labor Markets in LDCs: A Survey, September 2004

1282 Robert Dur and Amihai Glazer, Optimal Incentive Contracts for a Worker who Envies his Boss, September 2004

1283 Klaus Abberger, Nonparametric Regression and the Detection of Turning Points in the Ifo Business Climate, September 2004

1284 Werner Güth and Rupert Sausgruber, Tax Morale and Optimal Taxation, September 2004

1285 Luis H. R. Alvarez and Erkki Koskela, Does Risk Aversion Accelerate Optimal Forest Rotation under Uncertainty?, September 2004

1286 Giorgio Brunello and Maria De Paola, Market Failures and the Under-Provision of Training, September 2004

1287 Sanjeev Goyal, Marco van der Leij and José Luis Moraga-González, Economics: An Emerging Small World?, September 2004

1288 Sandro Maffei, Nikolai Raabe and Heinrich W. Ursprung, Political Repression and Child Labor: Theory and Empirical Evidence, September 2004

1289 Georg Götz and Klaus Gugler, Market Concentration and Product Variety under Spatial Competition: Evidence from Retail Gasoline, September 2004

1290 Jonathan Temple and Ludger Wößmann, Dualism and Cross-Country Growth Regressions, September 2004

1291 Ravi Kanbur, Jukka Pirttilä and Matti Tuomala, Non-Welfarist Optimal Taxation and Behavioral Public Economics, October 2004

1292 Maarten C. W. Janssen, José Luis Moraga-González and Matthijs R. Wildenbeest, Consumer Search and Oligopolistic Pricing: An Empirical Investigation, October 2004

1293 Kira Börner and Christa Hainz, The Political Economy of Corruption and the Role of Financial Institutions, October 2004 
1294 Christoph A. Schaltegger and Lars P. Feld, Do Large Cabinets Favor Large Governments? Evidence from Swiss Sub-Federal Jurisdictions, October 2004

1295 Marc-Andreas Mündler, The Existence of Informationally Efficient Markets When Individuals Are Rational, October 2004

1296 Hendrik Jürges, Wolfram F. Richter and Kerstin Schneider, Teacher Quality and Incentives: Theoretical and Empirical Effects of Standards on Teacher Quality, October 2004

1297 David S. Evans and Michael Salinger, An Empirical Analysis of Bundling and Tying: Over-the-Counter Pain Relief and Cold Medicines, October 2004

1298 Gershon Ben-Shakhar, Gary Bornstein, Astrid Hopfensitz and Frans van Winden, Reciprocity and Emotions: Arousal, Self-Reports, and Expectations, October 2004

1299 B. Zorina Khan and Kenneth L. Sokoloff, Institutions and Technological Innovation During Early Economic Growth: Evidence from the Great Inventors of the United States, 1790 - 1930, October 2004

1300 Piero Gottardi and Roberto Serrano, Market Power and Information Revelation in Dynamic Trading, October 2004

1301 Alan V. Deardorff, Who Makes the Rules of Globalization?, October 2004

1302 Sheilagh Ogilvie, The Use and Abuse of Trust: Social Capital and its Deployment by Early Modern Guilds, October 2004

1303 Mario Jametti and Thomas von Ungern-Sternberg, Disaster Insurance or a Disastrous Insurance - Natural Disaster Insurance in France, October 2004

1304 Pieter A. Gautier and José Luis Moraga-González, Strategic Wage Setting and Coordination Frictions with Multiple Applications, October 2004

1305 Julia Darby, Anton Muscatelli and Graeme Roy, Fiscal Federalism, Fiscal Consolidations and Cuts in Central Government Grants: Evidence from an Event Study, October 2004

1306 Michael Waldman, Antitrust Perspectives for Durable-Goods Markets, October 2004

1307 Josef Honerkamp, Stefan Moog and Bernd Raffelhüschen, Earlier or Later: A General Equilibrium Analysis of Bringing Forward an Already Announced Tax Reform, October 2004 